\title{
The Mediating Role of Opportunity of Participation Impact in Determining Training Effectiveness among Potential Entrepreneurs in Business Organisations
}

\author{
Muhammad Adamu ${ }^{1}$ \\ ${ }^{1}$ Department of Business Administration, Faculty of Social and Management Sciences, Bauchi State University, \\ Nigeria \\ Correspondence:Department of Business Administration, Faculty of Social and Management Sciences, Bauchi \\ State University, Nigeria, Tel: (+234) 08035558385,E-mail: majalamm@ gmail.com
}

Received: September 25, $2017 \quad$ Accepted: September 28, $2017 \quad$ Online Published: September 30, 2017

\begin{abstract}
The main objective of this study is to evaluate the training effectiveness on potential entrepreneurs through opportunity of participation given on a task in an organisation. The methodology used in this study is a survey research design through a quantitative approach. Questionnaires are used in collecting data in a cross-sectional survey. The data was analysed using the special package for social sciences (SPPS). Pearson's correlation co-efficient and regression analysis were conducted. Sobel test was also conducted to confirm the mediating effect of opportunity of participation. The findings revealed that there is a positive relationship between training effectiveness (Kirkpatrick Four Levels) and potential entrepreneur's performance. The regression analysis indicates opportunity of participation has been a dominant factor in the relationship between training effectiveness and potential entrepreneur's performance. The integration of a mediator in the frame contributes to Kirkpatrick model in the extant training and development as well as entrepreneurship literature. Furthermore, policy makers and HR departments of business organizations will have more appreciation of how training can be appropriately evaluated more particularly, the on-the-job training for an improved performance.
\end{abstract}

Keywords: Training Effectiveness, Kirkpatrick, Opportunity of Participation (Work Environment), Potential Entrepreneurs, Business Organisations.

\section{Introduction}

Present scenario of business world is characterized by a growing desire to have a very decent climate for the potential entrepreneurs to perform well as employees of an organisation for competitiveness, market globalization, and technological advances in organizations. (Bramley and Kitson, 2007). Many researchers have conducted a lot of studies in order to evaluate the training programmes, from the point of views of multiple factors and dimensions (Bramley and Kitson, 2007; Baldwin, 2008; Burke, 2006; Haslinda et al., 2009; Ibrahim et al., 2008; Richard et al., 2010, Wright, 2006). This is done for the purpose of ensuring that the skills learned during trainings are equally utilised by potential entrepreneurs in their new business start-up. This becomes imperative because the essence of acquiring training is to transfer it, or to apply it to the tasks by potential entrepreneurs. This, if properly conducted, would result in both the attainment of the business purposes as well as capability by potential entrepreneurs in their new business start-up. 
Following the completion of a training programme, and its subsequent application on the job, then it is worthy to be followed by evaluation to ascertain the effect of the training received by the potential entrepreneurs on the task they performed. The evaluation of a training programme in a business organisation is an ongoing process. Richard et al. (2010) are of the opinion that training evaluation can be done by considering learning process and job satisfaction. This shows that the gap between evaluation theory and practice is a serious problem for training in organisations and businesses. Studies on potential entrepreneurs performance has remained a multi-factorial exercise, taking different dimensions and views by many researchers. In his work, Baldwin (2008) found that the knowledge and skills of an individuals has become increasingly important to performance, competitiveness, and advancement, and as such, the knowledge, skills, and attitudes gained by the potential entrepreneurs through training has to be periodically evaluated over time so that their capability will match with the existing gaps and bridge the skills requirement needs on current and future task requirements.

Clarke (2012) believed that work environment is man's immediate surrounding which he manipulates for his existence. The productivity rate of the potential entrepreneurs in their business organization as well as their new business start-up is challenged by wrongful manipulation that brings hazards and makes the environments unfavourable. Therefore, in this direction, the workplace entails an environment in which the potential entrepreneurs tasks in their new business start-up. Also, Clarke (2012) found that work environment affect how potential entrepreneurs perform tasks in the organisation. This is so because the opportunity to participate in work has consequences regarding productivity level. Because today's business challenges is different, diverse, and constantly changing, the business environment is the most critical factor in keeping potential entrepreneurs satisfied in today's business world.

Therefore, the effectiveness of training can be ascertained and understood through training evaluation, and which is the intention of the researcher to evaluate training effectiveness, using the four levels of Kirkpatrick Model of training evaluation, and understanding the relationship between training effectiveness, and potential entrepreneur's performance, and the mediating role of opportunity of participation.

\section{Problem Statement}

Studies on potential entrepreneur's effectiveness have remained a multi-factorial exercise, taking different dimensions and views by many researchers. In his work, Baldwin (2008) found that the skills and knowledge of business organizations employees has become increasingly important to advancement, competitiveness and performance. Therefore, the knowledge, skills, and attitudes gained by the potential entrepreneurs through training has to be periodically evaluated over time so that their capability will match with the existing gaps and bridge the skills requirement needs on potential entrepreneurs in their new business start-up. A research by Kraiger and Ford (2008) shows that though many business organizations are concerned with the contribution of training to the potential entrepreneurs in their new business start-up. However, the feasibility of such validation and evaluation was not consistently ascertained.

In a research, Govindarajulu (2014) found that training evaluation does not exists at all in many business organizations or is carried out in a very casual way, and lack of this information makes it impossible to prove the value of training. Also Kirkpatrick (1998) found that organizations are not adept in utilizing the models to evaluate training programmes, and which has impact on performance. A gap of training evaluation and performance exists here, since without evaluating training, no value of training can be seen, and which is in a direct link with potential entrepreneur's performance.

If a training program is proven to be effective, it will definitely yield positive results. Kraiger (2008) concludes that measuring training is one of the key components on how an organization will succeed. and 
The Mediating Role of Opportunity of Participation Impact in Determining Training Effectiveness among Potential Entrepreneurs in Business Organisations

Muhammad Adamu

perhaps may yield more than what is expected by the organization. Govindarajulu (2014) argued for a significant relationship between training effectiveness and work environment on ensuring effectiveness and outcome achievement of training programme.

The work environment has great influence on the training effectiveness. Many literatures provide the evidence of significant relationship between environmental characteristics and training effectiveness, which is reflected directly in training outcomes (Elangovan and Karakowsky, 2010; Facteau et al., 2006; Goldstein, 2012). Other studies also emphasized different degrees of relationship between environmental characteristics and training effectiveness (Kraiger, 2008). In their findings Ibrahim et al. (2014) stated that the perception about the work environment in terms of participation will affect the potential entrepreneur's performance, which means that the provision of a conducives opportunity to participate by an organization will be able to improve potential entrepreneur's performance.

After reviewing these relevant studies as well as some verbal and written information received by the researcher, the researcher found it necessary to conduct this research for that there has been not so many researches conducted with regards to the impact of training on potential entrepreneurs performance of the sample organizations with similar variables of this study. Most of the researches reviewed were conducted based on qualitative approach (Burke and Baldwin, 2008). Therefore, there is the need to study it on quantitative method. Moreover, training evaluation has not been in practice by many business organizations to evaluate the level of potential entrepreneur's performance, and there is a conflicting view on the influence of work environment on training effectiveness. Moreover, the work environment factors are too many to be addressed on a single research, which might reduces the effectiveness of a research, and as such, the researcher explore on some of the relevant work environment factors. The work environment factors are relative upon business organizations, and the researcher chooses the ones that affect potential entrepreneur's performance relevant to the organisation of current study, hence potential entrepreneurs performance depends on training evaluation and some relevant work environment factors of a business organisation.

Therefore, for these purposes, the researcher will conduct a study on the relationship between training effectiveness (as an independent variable), and potential entrepreneurs performance (as a dependent variable) as well as determining the mediating role of work environment (as a mediating variable), and the use of Kirkpatrick model of training evaluation to specifically measure the training received by potential entrepreneurs in business organizations.

\section{Conceptual Framework}

The evaluation of this study is based on Kirkpatrick Model of Training Evaluation, in which employees are evaluated at the four levels of reaction, learning, behaviour, and results.

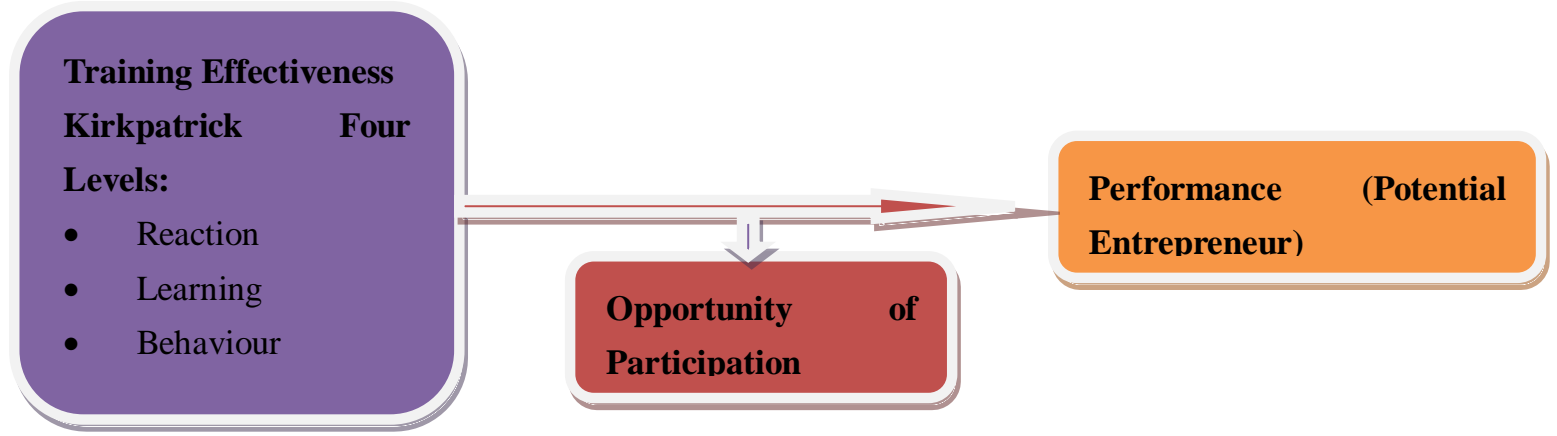

Source: Kirkpatrick, D. L. (1959).Techniques for Evaluating Training Programs. Journal of the American Society of Training and Development, 13, 3-9. 
The Mediating Role of Opportunity of Participation Impact in Determining Training Effectiveness among Potential Entrepreneurs in Business Organisations

Muhammad Adamu

\subsection{Specific Hypotheses}

$\mathbf{H}_{\mathbf{a} 1}$ : There is a significant relationship between training effectiveness and potential entrepreneur's performance.

$\mathbf{H}_{\mathbf{a} 2}$ : There is a significant influence of work environment (construct) on potential entrepreneur's performance.

$\mathbf{H}_{\mathbf{a} 3}$ : Opportunity of participation mediates the relationship between training effectiveness and potential entrepreneur's performance.

\subsection{Training Effectiveness}

Training effectiveness focuses on the characteristics of individuals, trainings, and organizational factors that affect training, before, during and after training. It pay more attention on the learning process as a whole, thus providing a macro view of training outcomes. Conducting a lot of training does not means that the training programmes were effective if there were no improvements in potential entrepreneurs performance and productivity. To ascertain the effectiveness of training, an evaluation is required. From the results of training evaluation, the business organizations will be able to ascertain more accurately whether the training received by potential entrepreneurs has been effective in the business organization, and subsequently in their new business start-up.

\subsection{Opportunity of Participation}

According to Ford et al. (2013), opportunity of participation is the extent to which an individual obtains work experiences relevant to the tasks is provided or through an activity for which he or she was trained. Potential entrepreneurs are supposed to get different opportunities to apply their training as these opportunities can affect the training outcomes. Low organizational performance would be manifest if the potential entrepreneurs do not have job opportunities to perform and transfer the new knowledge, skills and attitude on a given task in the business organization. Similarly, Clarke (2012) affirmed that training effectiveness can be undermined when heavy workload and time pressure are the main constraint against the opportunity to perform. The potential entrepreneur must have the opportunity to perform in order to ensure the training effectiveness. This will also help them to refine their knowledge, otherwise the knowledge and skills from the training will be forgotten. Learning opportunities in the job improve the employability of individual workers.

\subsection{Potential Entrepreneurs and Performance}

Potential entrepreneur's performance is a set of behavior which person show in relation to his task, or otherwise, amount of efficiency gained due to the person's type of job. It is efficiency in his role according to his legal tasks and the degree of efforts and successfulness of a person. It can be defined as the skills of potential entrepreneurs in doing a given task (DeSimeone and Werner, 2012). To improve business performance, it is usually a good idea to be on the lookout for new ways. Both at a managerial and employee level, improving business performance should be a concern of many business organisations. Productivity, reputation, employee morale and customer service may all improve greatly if a business organization is efficient and well-run. To get day to day work done, most organizations rely heavily on their employees. The janitor, the office worker, the floor supervisor, and even the cafeteria employees can all be a major factor in how good the company is and how efficiently it runs. It is important to listen carefully to employee feedback to improve business performance since many entry level and junior workers are on the ground floor of the company, they may be in the clearest position to be honest about possible improvement. Management and employees can go a long way toward improving business performance through creating an open dialogue about improvements by allowing a level of participation on task among the potential entrepreneurs within the organization which may later form their own business. 
The Mediating Role of Opportunity of Participation Impact in Determining Training Effectiveness among Potential Entrepreneurs in Business Organisations

Muhammad Adamu

\section{Research Methododlogy}

The research design for the conduct of this study is a survey research. It is one of the traditional and oldest research techniques (Babbie, 2014). Survey research is most often used to access about respondent's beliefs, attitudes, perceptions, and self reported behaviors (Kapoor 2008). The survey research was used test the hypotheses for this study, and to ascertain whether a possible relationship exists between training effectiveness, work environment, and potential entrepreneurs. The methodology used in this study based on quantitative research. Quantitative research was used to explore the relationship between training effectiveness, and potential entrepreneurs as well as determining the mediating role of work environment. The method used in this survey is the questionnaire method as a means of data collection from the respondents, and which is the easiest and quickest instrument to gather the respondent's views. The research design involves a sample of employees whom questionnaires were sent and filled, with regards to their opinions, feelings and perceptions. The training effectiveness is the independent variables; the work environment is the mediating variable, while potential entrepreneurs are the dependent.

\section{Findings of the Research}

\subsection{Relationship between the Kirkpatrick Levels of Training Evaluation and Potential entrepreneurs' performance}

According to Kirkpatrick (1996), the reaction, learning, behaviour and the results level of training evaluation influence a potential entrepreneur. From the findings of Kirkpatrick (1996), the construct of training evaluation is found to influence a potential entrepreneur.

This supported the following hypothesis:

$\mathbf{H}_{\mathbf{a} 1}$ : There is a significant relationship between training effectiveness and potential entrepreneur's performance.

Table 1: Pearson Correlation on the relationship between Reaction Level and Potential entrepreneur's performance

\begin{tabular}{llll}
\hline & & Reaction & Performance \\
\hline Reaction & Pearson Correlation & 1 & $.800^{* *}$ \\
& Sig. (2-tailed) & & .000 \\
& $\mathrm{~N}$ & & 107 \\
\hline Performance & Pearson Correlation & $.800^{* *}$ & 1 \\
& Sig. (2-tailed) & .000 & \\
& $\mathrm{~N}$ & 107 & \\
\hline
\end{tabular}

Table 1 above indicates that reaction level of training evaluation has a significant relationship with potential entrepreneurs at significant value, $\mathrm{p}=0.000$, which is less than $\mathrm{p}=0.01$. The results from the " $\mathrm{r}$ " value $\mathrm{r}=0.800$ translate a strong positive relationship between reaction level and potential entrepreneurs. Therefore, the first alternative hypothesis is accepted. ( $\mathrm{p}=0.000$, which is less than $\mathrm{p}=0.01, \mathrm{r}=0.800$ ). This findings is in line with the work of Baldwin (2008) who found that the knowledge and skills of an organizations employees has become increasingly important to performance, competitiveness, and advancement, as such, the knowledge, skills, and attitudes gained by the employees through training has to be periodically evaluated over time so that their capability will match with the existing gaps and bridge the skills requirement needs on current and future jobs requirements. 
The Mediating Role of Opportunity of Participation Impact in Determining Training Effectiveness among Potential Entrepreneurs in Business Organisations

Muhammad Adamu

Table 2: Pearson Correlation on the relationship between Learning Level and Employee Performance

\begin{tabular}{llll}
\hline & & Learning & Performance \\
\hline Learning & Pearson Correlation & 1 & $.770^{* *}$ \\
& Sig. (2-tailed) & & .000 \\
& $\mathrm{~N}$ & & 107 \\
\hline Performance & Pearson Correlation & $.770^{* *}$ & 1 \\
& Sig. (2-tailed) & .000 & \\
& $\mathrm{~N}$ & 107 & \\
\hline
\end{tabular}

Table 2 above indicates that learning level of training evaluation has a significant relationship with potential entrepreneurs at significant value, $p=0.000$ which is less than $p=0.01$. The results from the " $r$ " value $r=0.770$ translate a strong positive relationship between learning level and potential entrepreneurs. Therefore, the first alternative hypothesis is accepted. ( $\mathrm{p}=0.000$, which is less than $\mathrm{p}=0.01, \mathrm{r}=0.770)$.

Table 3: Pearson Correlation on the relationship between Behaviour Level and Potential Entrepreneurs

\begin{tabular}{llll} 
& \multicolumn{3}{c}{ Performance } \\
\hline Behaviour & Pearson Correlation & Behaviour & Performance \\
& Sig. (2-tailed) & 1 & $.402^{* *}$ \\
& $\mathrm{~N}$ & & .000 \\
& Pearson Correlation & 107 \\
\hline Performance & Sig. (2-tailed) & $.402^{* *}$ & 1 \\
& $\mathrm{~N}$ & .000 & \\
\hline
\end{tabular}

Table 3 above indicates that learning level of training evaluation has a significant relationship with potential entrepreneurs at significant value, $p=0.000$ which is less than $p=0.01$. The results from the " $r$ " value $r=0.402$ translate a moderate positive relationship between behaviour level and potential entrepreneurs. Therefore, the first alternative hypothesis is accepted. $(\mathrm{p}=0.000$, which is less than $\mathrm{p}=0.01, \mathrm{r}=0.402$ ).

Table 4: Pearson Correlation on the relationship between Results Level and Potential Entrepreneurs

\begin{tabular}{llll} 
& & Performance & \\
\hline \multirow{2}{*}{ Results } & Pearson Correlation & Results & Performance \\
& Sig. (2-tailed) & 1 & $.876^{* *}$ \\
& $\mathrm{~N}$ & & .000 \\
& Pearson Correlation & $.876^{* *}$ & 107 \\
\hline Performance & Sig. (2-tailed) & .000 & 1 \\
& $\mathrm{~N}$ & 107 & \\
\hline
\end{tabular}

Table 4 above indicates that results level of training evaluation has a significant relationship with potential entrepreneurs at significant value, $p=0.000$ which is less than $p=0.01$. The results from the " $r$ " value $r=0.876$ translate a very strong positive relationship between results level and potential entrepreneurs. Therefore, the first alternative hypothesis is accepted. ( $\mathrm{p}=0.000$, which is less than $\mathrm{p}=0.01, \mathrm{r}=0.876$ ). 
The Mediating Role of Opportunity of Participation Impact in Determining Training Effectiveness among Potential Entrepreneurs in Business Organisations

Muhammad Adamu

\subsection{Pearson's Correlation on the relationship between Organization's Culture and Potential Entrepreneurs}

\section{Performance}

$\mathbf{H}_{\mathrm{a} 2}$ : There is a significant influence of work environment (construct) on potential entrepreneurs.

Table 5: Pearson Correlation on the relationship between Participation Level and Potential entrepreneur's

\begin{tabular}{|c|c|c|c|}
\hline & & Participation & Performance \\
\hline \multirow[t]{3}{*}{ Participation } & Pearson Correlation & 1 & $.725^{* *}$ \\
\hline & Sig. (2-tailed) & & .000 \\
\hline & $\mathrm{N}$ & & 107 \\
\hline \multirow[t]{3}{*}{ Performance } & Pearson Correlation & $.725^{* *}$ & 1 \\
\hline & Sig. (2-tailed) & .000 & \\
\hline & $\mathrm{N}$ & 107 & \\
\hline
\end{tabular}

Table 5: above indicates that opportunity of participation as a construct of work environment has a significant relationship with potential entrepreneurs at significant value, $p=0.000$, which is less than $p=0.01$. The results from the "r" value $r=0.725$ translate a strong positive relationship between opportunity of participation and potential entrepreneurs. Therefore, the second alternative hypothesis is accepted. ( $\mathrm{p}=0.000$, which is less than $\mathrm{p}=0.01, \mathrm{r}=0.725$ ).

This finding is in line with Christopher and Khann (2013) that the opportunity to participate as a work environment construct is an employee's immediate surrounding which he manipulate for his existence. Facteau (2006) also indicates that environmental conditions affect employee safety perceptions which have impact upon employee commitment in the workplace.

\subsection{Testing the Mediating Variables}

Table 6: Results for Stepwise Regression Analysis with Opportunity of participation (Work Environment) as the Mediator, and Training Effectiveness as the Independent Variable

$\mathbf{H}_{\mathbf{a} 3}$ : Opportunity of participation mediates the relationship between training effectiveness and potential entrepreneurs.

\section{Model Summary}

\begin{tabular}{lllll}
\hline Model & R & R Square & Adjusted R Square & Std. Error of the Estimate \\
\hline 2 & $.982^{\mathrm{a}}$ & .965 & .963 & .08821 \\
\hline
\end{tabular}

a. Predictors: (Constant), Participation, Learning, Behavior, Results, Reaction

\section{Model 1}

Model 2

Model 3

Independent

Variables:

Reaction

Learning

Behaviour

Results

Mediating Variable:

Opportunity of

participation 
In Table 6 above, the result of this study confirmed that opportunity of participation is statistically in significant linear relationship based on the perception of employees with the dependent variables since it is significant at $\mathrm{p}=0.003$, which is less than $\mathrm{p}=0.01$, therefore, the fourth alternative hypothesis is accepted, and it can be assumed as the dominant factor contributing to the potential entrepreneurs.

\subsection{Results for Sobel Test on Mediating Variables}

The results of the Sobel test on organisation culture mediation shows that the Test statistics value $=2.203$, the Standard error value $=0.717$, and the $p$ value $=0.009$. This shows that opportunity of participation mediates positively in the relationship between training effectiveness and potential entrepreneurs, and it is considered as a dominant factor at $(\mathrm{p}=0.01)$.

\subsection{Discussion}

This study was conducted by survey on the sample organization with the total 107 respondents as the sample of the study. The result of this study confirmed that training effectiveness is a major and crucial factor that influences the potential entrepreneur's performance. The Kirkpatrick four levels of training evaluation to determine the impact of training effectiveness towards potential entrepreneurs were found to have a positive relationship towards influencing business performance. Opportunity of participation mediates positively in the relationship between training effectiveness and potential entrepreneur's performance.This shows that opportunity of participation has a mediating influence towards effective performance of potential entrepreneurs in business organizations. When making decisions about the best methods to generate business achievements in their complex environments, organizational leaders are confronted with many complex issues. Thus, the sample organization should do everything possible to ensure that every training provided on the task as a participation by to the potential entrepreneurs should be evaluated at the four levels so that gaps and training needs should be identified, and corrective actions has to be consistently taken.

\subsection{Implications}

The results of this study will enrich the Kirkpatrick Training Evaluation Theory and Model, the Ludwig Open System Theory (System theory), and the Don Elger Theory of Performance that support the hypotheses of this study, in enhancing future research on the relationship between training effectiveness and potential entrepreneurs performance, and the mediating role of work environment by developing a relevant model in the future researches. Future researchers can make further investigations to get more accurate data and reliable information, in terms of the instruments used in this study. By identifying the relationship between training effectiveness and potential entrepreneurs performance, and the mediating role of opportunity of participation, the advantages of understanding how training can be evaluated appropriately, as well as also appreciating the environmental factors that can influence the performance of potential entrepreneurs by policy makers and HR department of the sample organization. This would allow the organization to remain proactive in the issues relating to training and its evaluation, and the environmental context and influence of work environment factors on potential entrepreneurs in a reduced cost within a specified period of time.

\section{Limitations of the Research}

This research concentrated only on training effectiveness as an independent variable, and work environment as a mediating variable, while potential entrepreneurs performance as a dependent variable. Therefore, other researches should be conducted using different variables to proliferate the validity and reliability of this research. Another limitation of this research is that its performance evaluation is only based on the sample organisation's employees; other researches may be conducted beyond this. 
The Mediating Role of Opportunity of Participation Impact in Determining Training Effectiveness among Potential Entrepreneurs in Business Organisations

Muhammad Adamu

\section{Recommendation of the Research}

Relatively, this research is important to business organizations in the way they can evaluate the employees training programs in such a way that it can be result oriented, thereby meeting the purpose and targets upon the employees, towards a successful task completion within time frame and with less cost that would firmly put the organisation on the path towards the accomplishment of it's goals and objectives, which is a bedrock for performance and productivity. The HR department of the business organisations should take in to consistent consideration about the four levels of evaluating a training program that has an influence on potential entrepreneurs performance, as well as the work environment factor (opportunity of participation) that also influence potential entrepreneurs performance. The population of this research is from a business organisation, because of the scope and limitation of this study. Future researchers should extend it to include public organisations. The sample size should also be increased to have a larger sample size in future research by other researchers. The method of data collection should also be enhanced, qualitative, and the combination of qualitative and quantitative research approach can both be used to improve the quality and reliability of the future research. The instrument to be used should include, in addition, an interview method. This, together with the questionnaire method, would improve the validity and reliability of the future researches, and hence, a way forward.

\section{Conclusion}

In conclusion, the Kirkpatrick four levels of training evaluation and the work environment construct has a positive correlation relationship with potential entrepreneur's performance. The stepwise regression analysis was used to determine the mediating role of work environment (organization's culture), in the relationship between training effectiveness (reaction, learning, behaviour, and results) and potential entrepreneur's performance. The findings revealed that opportunity of participation act as a mediator and a dominant factor in the relationship between training effectiveness and potential entrepreneur's performance. The regression analysis results show that opportunity of participation mediate positively in the relationships between training effectiveness and potential entrepreneur's performance.

\section{References}

Babbie, E. (2014) The practice of social research $\left(9^{\text {th }}\right.$ Ed.) Belmont, California: Journal of Applied Psychology Thompson and Wardsworth Publishing Co.

Baldwin, J. and Ford, R. (2008) A cumulative study of the effectiveness of managerial training Journal of Applied Psychology, 71, 232-245 Publishing Co.

Bramley J. and Kitson, C. (2007) Characteristics on measures of training effectiveness. Academy of Management Journal, 35(4), 828- 847

Bransford, M. (2008) Theory of performance, expectations of faculty in higher eduction by Don Elger, University of Idaho

Christopher M. and Khann K. (2013) Impact of work environment on performance of employees in manufacturing sector in india: literature review International Journal of Science and Research (IJSR) ISSN (Online): 2319-7064 Index Copernicus Value (2013): 6.14 | Impact Factor (2015): 6.391 Volume 5 Issue 4, April 2016 www.ijsr.net Licensed Under Creative Commons Attribution

Clarke, N.\& Hung (2012). Job/Work Environment Factors Influencing Training Transfer Within A Human Service Agency: Some Indicative Support for Baldwin and Ford's Transfer Climate Construct. International Journal of Training and Development, 6(3), 146-162.

Burke, J. and Day, R. (2011) A cumulative study of the effectiveness of managerial training Journal of Applied 
The Mediating Role of Opportunity of Participation Impact in Determining Training Effectiveness among Potential Entrepreneurs in Business Organisations

Muhammad Adamu

Psychology, 71, 232-245.

De Simeone, U. and Werner, K. (2012) Human resource development, Sixth Edition, South- Western, Cengage Learning, International Edition. www.cengage.com/permissions.

Dwyer, J., Richard L., and Salas, E. (2010) Performance measurement in distributed environments: Initial results and implications for training. Military Psychology, 11, 189-215

Elangovan, A. and Karakowsky, L. (2010). The Role of Trainee and Environmental Factors in Transfer of Training: An Exploratory Framework. Leadership and Organization Development Journal, 20(5), 268-276.

Facteau, J. Dobbin, C. Russell, H. and Ladd V. (2006) The influence of general perceptions of the training environment on pre-training motivation and perceived training transfer. Journal of Management, $21(1), 1$.

Ford, K. and Quiñones, R. (2010) Factors affecting the opportunity to perform trained tasks on the job. Journal of social Psychology, 45(3), 511-527.

Govindarajulu, N. and Daily N. (2014) Motivating employees for environmental improvement. Industrial Management and Data Systems Journal 104(4), 364-372.

Goldstein, I. and Ford, J. K. (2012) Training in organizations: Needs assessment, development, and evaluation (4th ed.). Belmont, CA:Wadsworth

Haslinda, A. and Mahyuddin, M. (2009) The effectiveness of training in the public service American Journal of Scientific Research ISSN 1450-223X Issue 6 pp.39-51@ EuroJournals Publishing, Inc. 2009http://www.eurojournals.com/ajsr.htm

Ibrahim, M. E. (2008) Measuring Training Effectiveness Journal of Management Research, 4(3), 147- 155.

Ibrahim, A. (2008) Evaluating training effectiveness in the malaysian public service, Durham theses, Durham University. Available at Durham E-Theses Online: http://etheses.dur.ac.uk/2176

Kapoor, J. (2002) Problems and Solutions in Statistics, $6^{\text {th }}$ Ed. Chally Press, New Delhi, India.

Kirkpatrick, D. L.(1996) Invited reaction: reaction to holton article. Human Resource Development Quarterly Journal 7, 23-25.

Kraiger, K. and Ford, C. (2008) Application of cognitive, skill-based, and affective theories of learning outcomes to new methods of training evaluation. Journal of Applied Psychology, 78, 311-328.

Krejcie, R. and Morgan, D. (1970) Determining Sample Size for Research Activities. Educational and Psychological Measurement

Ludwig V. B. (1901-1972): A Pioneer of General Systems Theory

Raja, K., Furqan, K. and Muhammad, K. (2011) Impact of Training and Development on Organizational Performance Global Journal of Management and Business Research Volume 11 Issue 7 Version 1.0 Double Blind Peer Reviewed International Research Journal Publisher: Global Journals Inc. (USA) Print ISSN: 0975-5853

Wright, M., McMahan, C. and McWilliams, A. (2006) Human resources and sustained competitive advantage: a resource-based perspective International Journal of $\quad$ Human Resource Management,5(2): 301-26.

\section{Copyrights}

Copyright for this article is retained by the author(s), with first publication rights granted to the journal. 